\title{
EFFECT OF THREE CONTROL TACTICS IN INTEGRATED PEST MANAGEMENT ON THE POPULATION OF POTATO TUBER MOTH PHTHORIMAEA OPERCULELLA (ZELLER) ( LEPIDOPTERA : GELECHIIDAE ) IN POTATO FIELDS .
}

\author{
OMAR , H.I.H. ${ }^{1}$, M.A.A.M.EL- AW ${ }^{2}$, K.A.A.A.DRAZ ${ }^{2}$, MAHA.A.M.TANTAWY ${ }^{1}$ \\ AND ENAS M.A.GHAZALA ${ }^{1}$ \\ 1 -Vegetable, Insect Research Dep. Plant. Protection. Res. Inst., ARC, Giza . \\ 2 - Fac. Agric . Alex. University, Damanhour.
}

(Manuscript received 5 December 2010)

\begin{abstract}
The study aimed to investigate IPM techniques which would reduce potato tuber moth (PTM), Phthorimaea operculella (Zeller ) (Lepidoptera : Gelechiidae ), population in potato fields. Three IPM techniques, potato planting date, sex pheromone-baited water traps and the bioinsecticides were tested. Results indicated that early planting of potato summer plantation in January, significantly reduce the population of $\underline{p h}$. operculella larvae from four tested planting times. Sex pheromone - baited water traps. were effective as a means of detecting and monitoring the occurrence of adults of Ph . operculella in both seasons of 2004 and 2005 . Moreover potato plants in fields containing traps were statistically less infested with Ph. operculella than plants in field without traps by \% reduction amounted $21.7 \%$ in winter plantation and $27.1 \%$ in summer plantation. The correlation between catches of potato tuber moth males and each of max and min temperature in winter plantation were significant. Spraying of potato plants with bioinsecticides significantly reduced number of PTM larvae. Spinosad ( Tracer $24 \%$ SC ) was the most effective insecticide followed by botanical insecticides Azadirachtin (Achock $15 \%$ EC ) and Soybean oil ( Naturals $96 \%$ EC ). Thus early planting of potato summer plantation in January, Sex pheromone - baited water traps and bioinsecticides may be a promising components of IPM strategies for reducing Ph. operculella population in potato fields .
\end{abstract}

\section{INTRODUCTION}

Potato Solanum tuberosum L. considered one of the most important vegetable crop in Egypt. Potato tuber moth ( PTM ), Phthorimaea operculella (Zeller) (Lepidoptera : Gelechiidae), is a serious pest of solanaceous crops including potato, and tomato and is widely distributed in the temperature and subtropical regions (Sporleder et al., 2004). The suitable planting dates were determined by sever investigators (Fetoh 2003 and Abbassy, et al., 2008), in order 
to gain high yield as a result of low infestation by PTM. Also, There was a highly significant positive correlation was stated by (Fetoh 2003) between the collected moths by sex pheromone and prevailed temperature, On other hand the infestation with PTM larvae in field treated with pheromone traps was drastically less than fields without pheromone trap. Biological control of this pest has had limited success, therefore chemical control remains the most widely used method. The new products with favorable environmental characteristics are required for management of this pest in Egypt (Raslan ,et al., 2009). Therefore, the objective of this study was to investigate, IPM techniques for control of this PTM in potato plants based on avoiding, as much as possible, foliar spraying with synthetic insecticides. Three IPM techniques, planting date of potato plants, the use of sex phermon -baited water traps, and foliar spraying with bioinsecticides, spinosad, Soybean oil and azadirachtin were tested.

\section{MATERIALS AND METHODS}

\section{1-Effect of potato planting dates on PTM Infestation :-}

The effect of potato planting dates on the level of infestation by PTM larvae was studied in two successive years on Hermis variety during season of 2004 and 2005 in Etay El-Baroud Agric. Res. Station, A.R.C. in El-Behera Governorate. The tested planting dates were $23^{\text {rd }}$ of January, $10^{\text {th }}, 23^{\text {rd }}$ of February and $10^{\text {th }}$ March during summer of 2004 and 2005 . The experimental area was 16 Kerate $\left(2800 \mathrm{~m}^{2}\right.$ ), divided to four blocks as replicates and each block included four plots to represent four planting dates. After 30 days from planting, the potato plants were examined weekly until harvest time. Where,25 potato leaves were chosen randomly from each plot and identified by Biological control department, Plant Protection Research Institute and inspected carefully to record PTM larvae infestation on potato leaves. F test analysis was applied to compare among the four planting dates to declare the planting date of potato which gives low infestation.

\section{2- Effect of sex pheromone traps :-}

To evaluate the efficiency of sex pheromone traps for monitoring the changes in population density of PTM males at potato field in El-Delangate region in El-Behera Governorate, sex pheromone trap ( Water pan traps ) were made of plastic material in oblong shape ( $30 \times 20 \times 10 \mathrm{~cm}$ ) and placed in field at $1.20 \mathrm{~cm}$ height from ground level. Pheromone substance was impregnated in capsules and 
kept frozen to preserve their effectiveness until using . It was exchanged every two weeks. The traps were filled with a mixture of water and detergent. Water was changed when it is needed. The sex pheromone capsules, used in this study were obtained from Pheromone Production Unit, Plant Protection Research Institute, Agriculture research Center. The experimental area was one feddan for each of winter and summer plantation in 2004 and 2005 seasons. The traps were distributed at four cardinal directions ( South , North , West, and East ) and one trap at the center of potato field. Weekly numbers of potato tuber moth males were recorded in traps in the different directions. Moreover, samples of $25 \times 4$ potato leaves were chosen randomly from fields treated with pheromone traps and compared with similar samples collected from potato fields untreated with pheromone traps. Larvae was identified as Phthorimaea operculella (Zeller) by Biological Control Department, Plant Protection Research Institute. This procedure was conducted from 37 days of potato plant age in summer plantation and 51 day in winter plantation until harvest time. On other hand, records of daily means temperature and relative humidity were obtained from El-Delengate Metrological Station . From these records means of maximum and minimum temperature as well as mean relative humidity were calculated 7 days earlier from corresponding sampling dates. The pheromone substance is a sex attractive consisted of a mixture of two synthetic components PTM1 (Trans-4, cis-7-Tridecadien-1-01 acetate ) and PTM2 (Trans-4, cis-7, cis-10Tridecadien 1-01 acetate) in a ratio $0.4 \mathrm{mg}$ of PTM! and $0.6 \mathrm{mg}$ of PTM2.

\section{3-Effect of certain natural products :-}

An experiment was conducted to evaluate efficiency of three natural products against $P h$. operculella under field conditions, The experimental area of approximately one Fadden $\left(4900 \mathrm{~m}^{2}\right)$ was cultivated on 10-March with potatoes plants variety (Nicola) in El-Dalangat Region, El-Behera Gavornorate, during winter plantation of 2004, 2005, summer plantation of 2005. Three natural products were tested in two different concentrations for each pesticide. So experimental area of $\left(4900 \mathrm{~m}^{2}\right)$ was divided into four blocks then each block was divided to seven plots (six plots treated with the three natural products at two different rates and one plot was left without spraying as control). Three sprays were conducted in 65 days of plant age by a Knepsak sprayer. Samples of 10 potato leaves were chosen randomly from each tested plot, pre and post each spraying to determine initial infestation and reducing in infestation level, respectively. The percentage 
of potato tuber moth larvae reduction (Morlatity) was calculated according to (Henderson and Tiliton equation 1955) as follow :-

Reduction $\%=[1-(\mathrm{Cb} \times \mathrm{Ta} / \mathrm{Ca} \times \mathrm{Tb})] 100$ Where $\mathrm{T}$ : Number of live insect individuals in treatment. C: Number of live insect individuals in control. A : Number of live insect individuals after treatment. B : Number of live insect individuals before treatment.

\section{Tested Natural products :-}

1. Spinosad : (a mixture of spinosyn A and spinosyn D . both are secondary metabolite of soil actinomycete Saccharopolysporo spinosad as Tracer 24\% $S C)$

2. Azadirachtin : (extracted from the neem tree Azadiracta indicce as Achook $0.15 \%$ E.C. )

3. Soybean oil (Extracted from Soybean plant as Naturals $96 \%$ E.C.)

\section{RESULTS AND DISCUSSION}

\section{1- Effect of planting date :-}

Statistical analysis revealed that planting dates of potato plants significantly affected Ph.operculella larval population in both seasons of 2004 and 2005 as shown in the Table (1).The lowest infestation occurred when potato was sown in January $23^{\text {rd }}(5.84-3.98$ larvae / 25 potato leaves ), while the highest one was achieved when potato plant was sown in $10^{\text {th }}$ March $(10.95-6.80$ larvae / 25 potato leaves ). This variation in Ph. operculella infestation is due to changes in prevailing weather conditions and other ecological factors. Thus culture management, such as early cultivation of potato plants can reduce its infestation with Ph .operculella. This agrees with the results given by (Fetoh 2003 and Abbassy,et al., 2008 ) .Therefore, the recommended dates for planting of potato plants is in January to reduce the population density of Ph. operculella . 


\section{2-Effect of sex pheromone traps :-}

Sex pheromone-baited water traps were effective as a means of detecting and monitoring the occurrence of adults of Ph.operculella in both seasons of 2004 and 2005 as shown in Table (2). The mean number of 25.33 and 209.04 adult males was caught during winter and summer plantation in 2004 and 2005 , respectively. Moreover, potato plants in fields containing traps were statistically less infested with Ph.operculella than plants in field without traps, the mean total number of PTM larvae / 100 potato leaves being 13.8 in 2005 summer plantation, and 3.33 in 2004 - 2005 winter plantation in field with traps, as compared with 50.9 and 15.83 larvae / 100 potato leaves in fields without traps in El-Behera Governorate by \% reduction $21.3 \%$ ( $3.33 \backslash 15.83 \times 100)$ in winter plantation and $27.3 \%$ ( $13.0 \backslash 50.9 \times 100)$ in summer plantation. Traps were also useful in detecting and monitoring the first occurrence of the gelechiid and its population fluctuations as reported by ( Doss, 1984). A positive correlation between $\max . \min$. temperature were detected in winter plantation and survival of Ph.operculella. The correlation between catches of potato tuber moth males and each of $\max$. and $\min$. temperature in winter plantation were significant represented by $0.792 * * *$ and $0.857^{* * *}$ respectively, but not significant in summer plantation ( $0.54,0.533$ and 0.329 ). This results agree with ( Fetoh 2003). Thus, the use of sex pheromone traps will provide the grower with an additional tool of IPM for control of Ph. operculella on potato plants with less environmental impact and increased applicator and consumer safety compared to standard technology (using of synthetic insecticides as foliar spray) as reported by (Mullins 1993 ).

\section{3-Effect of bioinsecticides :-}

Bio-insecticides are environmentally safer and more economical ( Kirschbaum 1985 ). They emerged as powerful alternatives to conventional chemical insecticides ( Hofte and Whiteley, 1989 ). Spinosad is a broad- spectrum bacterial insecticide, represent a novel class of macrocyclic lactones produced by the soil actinomycete Saccharopolyspora Spinosa (Mertz and Yao, 1990). Result in Table (3) revealed that spraying of potato plants with spinosad at 30 and 20 $\mathrm{ml} \mathrm{/100} \mathrm{L} \mathrm{water} \mathrm{resulted} \mathrm{in} 93.39 \%$ and $88.4 \%$ reduction in winter $2004 /$ 2005 plantation season and $92.51 \%$ and $90.26 \%$ reduction in 2005 summer plantation , of PTM larvae respectively. This may be due that spinosad proved to reduce significantly egg-adult survivorship (Liu and Trumble 2005 ). It 
important to define the minimum effective rate of spinosad to PTM control, not only for economical reasons but also to minimize the potential impact on non- target organisms (Boyd and Boethel 1998). Of the botanical insecticides tested to data, the insecticide effects of azadirachtin, are strongly antifeedant, insect growth regulator and reproductive effects ( Mordue and Blackwell 2003 ). Results in Table (3) revealed that foliar spray of potato plants with azadirachtin at rates of 187.5 , and $140 \mathrm{ml} / 100 \mathrm{~L}$. water caused significant reduction of larvae population of PTM Ph.operculella. The mean of corrected mortality percentage three foliar spraying was 80.64 and 80.78 at the $187.5 \mathrm{ml} / 100 \mathrm{~L}$ water during winter plantation of 2004 / 2005 season and summer plantation of 2005 season, respectively. While it was at the reduced dose ( $140.0 \mathrm{ml} / 100 \mathrm{~L}$ water) $74.92 \%$ and $70.48 \%$ during winter plantation of 2004 / 2005 and summer plantation of 2005 seasons respectively. Similary (Abbassy,et al., 2008 ) found that no adult emerged from neem treated leaves with 0.025 to $0.1 \mathrm{~g}$ of azadirachtin . Very few data are available on the insecticide activity of natural oils based bioinsecticides against the PTM Ph.operculella on potato plants. Result in Table (3) indicated that the foliar spray of potato plants with the Soybean oil (Natural 96\% E.C.) showed significant reduction on larvae numbers of this PTM. Three applications of $625 \mathrm{ml} / 100 \mathrm{~L}$ resulted in $58.66 \%$ reduction in larvae. There are significant differences between recommended and $468 \mathrm{ml}$ rates of soybean oil. The effect ( as \% reduction ) was decreased to $43.87 \%$, and $51.38 \%$ respectively . In this respect , (Amany, et al., 2010) reported that plant extracts proved to be a safe alternative pest control trend rather than tradional pesticides. In conclusion, the overall results indicate that early planting of potato plant, in January, sex pheromone- baited water traps, and foliar spraying of potato plants with the bioinsecticides, spinosad and zadirachtin may be effective IPM strategies for reducing $P h$. operculella population in the potato fields. 
Table 1. Effect of Potato planting date on the population density of Ph. opercullela during in 2004 and 2005 summer plantation at Etay ElBaroud Agric.Res. Station in El-Behera Governorate .

\begin{tabular}{|c|c|c|c|c|}
\hline \multirow{3}{*}{ Plant age (days) } & \multicolumn{4}{|c|}{ Mean Number of larvae / 25 potatos \leaves $( \pm$ S.D) } \\
\hline & 23 January & 10 February & 23 February & 10 March \\
\hline & \multicolumn{4}{|c|}{ Summer 2004} \\
\hline 30 & 0.00 & 0.00 & 0.00 & $2.50 \pm 0.65$ \\
\hline 37 & 0.00 & 0.00 & $5.25 \pm 1.11$ & $5.50 \pm 0.65$ \\
\hline 44 & 0.00 & $5.50 \pm 0.65$ & $6.50 \pm 0.87$ & $7.50 \pm 1.19$ \\
\hline 51 & $5.50 \pm 0.65$ & $6.25 \pm 0.63$ & $7.75 \pm 1.93$ & $8.75 \pm 1.65$ \\
\hline 58 & $5.00 \pm 0.82$ & $7.50 \pm 0.87$ & $7.75 \pm 0.48$ & $11.00 \pm 0.92$ \\
\hline 65 & $6.25 \pm 1.11$ & $10.25 \pm 0.63$ & $10.25 \pm 1.38$ & $12.25 \pm 0.75$ \\
\hline 72 & $7.75 \pm 1.75$ & $10.00 \pm 0.71$ & $10.00 \pm 2.62$ & $12.75 \pm 1.65$ \\
\hline 79 & $8.25 \pm 1.32$ & $12.25 \pm 0.86$ & $12.50 \pm 1.56$ & $14.75 \pm 1.80$ \\
\hline 86 & $10.00 \pm 1.47$ & $12.50 \pm 1.94$ & $13.25 \pm 1.80$ & $15.00 \pm 1.42$ \\
\hline 93 & $10.50 \pm 1.71$ & $12.75 \pm 1.25$ & $13.75 \pm 2.35$ & $15.00 \pm 2.60$ \\
\hline 100 & $11.00 \pm 2.12$ & $13.75 \pm 1.70$ & $14.00 \pm 2.68$ & $15.50 \pm 2.73$ \\
\hline Total & 64.25 & 90.75 & 101 & 120.5 \\
\hline Mean & $5.84 \mathrm{c}$ & $8.25 b$ & $9.18 b$ & $10.95 \mathrm{a}$ \\
\hline \multicolumn{5}{|c|}{ L.S.D $0.5=1.191$} \\
\hline \multicolumn{5}{|c|}{ Summer 2005} \\
\hline 30 & 0.00 & 0.00 & 0.00 & $1.00 \pm 0.41$ \\
\hline 37 & 0.00 & 0.00 & $1.00 \pm 0.41$ & $1.00 \pm 0.58$ \\
\hline 44 & 0.00 & $1.00 \pm 0.58$ & $1.00 \pm 0.73$ & $2.00 \pm 0.41$ \\
\hline 51 & 0.00 & $3.25 \pm 0.25$ & $4.00 \pm 1.47$ & $4.25 \pm 0.48$ \\
\hline 58 & $2.00 \pm 0.41$ & $3.50 \pm 0.65$ & $4.50 \pm 1.23$ & $5.00 \pm 0.41$ \\
\hline 65 & $3.50 \pm 0.29$ & $6.00 \pm 1.08$ & $6.75 \pm 1.11$ & $6.75 \pm 0.25$ \\
\hline 72 & $3.75 \pm 0.48$ & $7.50 \pm 1.90$ & $8.00 \pm 0.82$ & $9.00 \pm 0.41$ \\
\hline 79 & $7.75 \pm 0.48$ & $7.75 \pm 0.63$ & $8.50 \pm 1.71$ & $10.00 \pm 1.08$ \\
\hline 86 & $8.00 \pm 0.71$ & $9.00 \pm 1.47$ & $9.50 \pm 1.26$ & $11.75 \pm 1.18$ \\
\hline 93 & $8.75 \pm 0.48$ & $9.50 \pm 0.50$ & $10.00 \pm 1.08$ & $12.00 \pm 0.58$ \\
\hline 100 & $10.00 \pm 0.82$ & $10.25 \pm 0.83$ & $10.50 \pm 1.19$ & $12.00 \pm 0.92$ \\
\hline Total & 43.75 & 57.75 & 63.75 & 74.75 \\
\hline Mean & $3.98 \mathrm{c}$ & $5.25 \mathrm{~b}$ & $5.80 \mathrm{~b}$ & $6.80 \mathrm{a}$ \\
\hline
\end{tabular}


Table 2. Weekly numbers of Ph. oprculella males captured in pheromone traps, numbers of larvae on potato plants and the

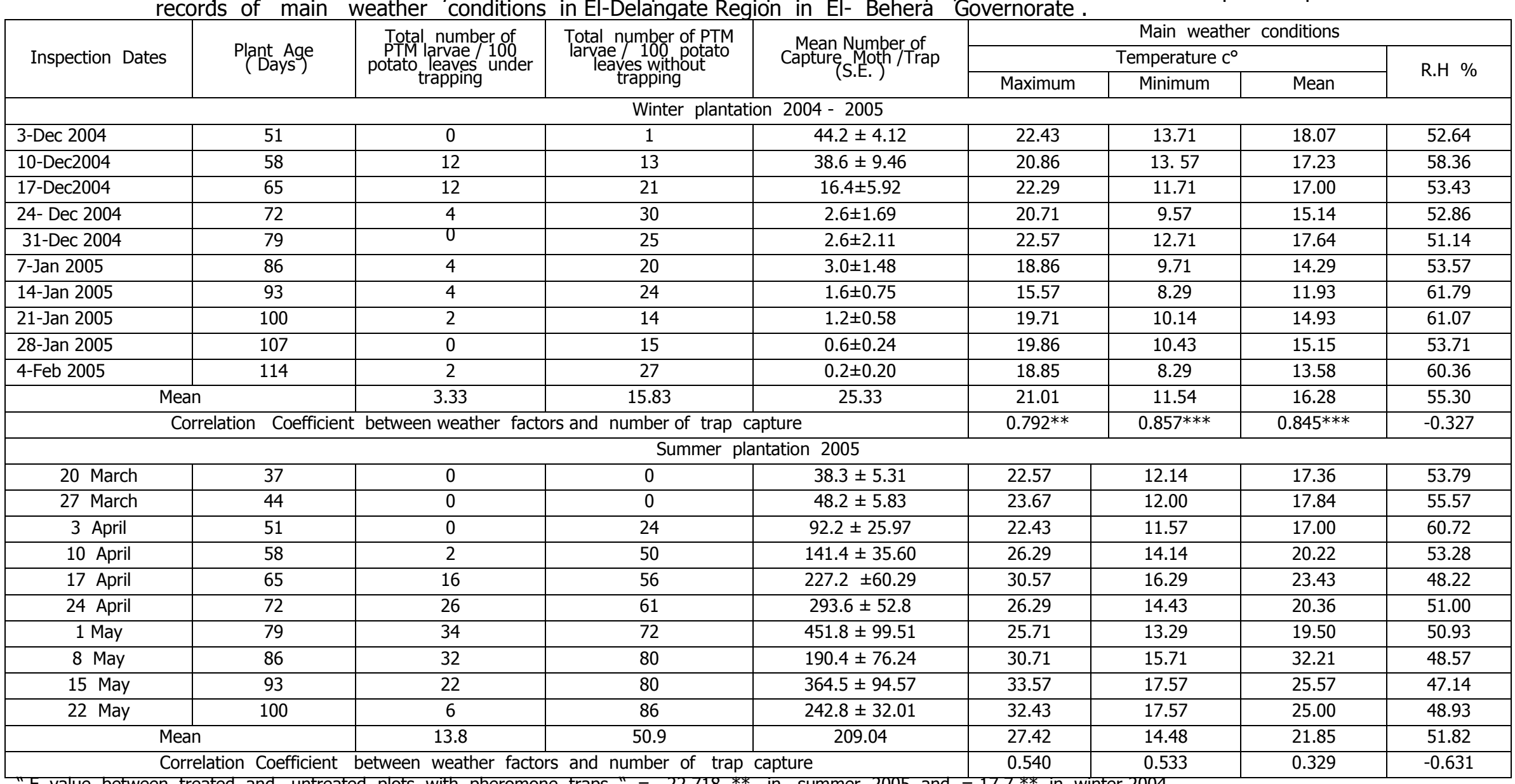

"F value between treated and untreated plots with pheromone traps " $=22.718 * *$ in summer 2005 and $=17.7^{* *}$ in winter 2004 
Table 3. Efficacy of certain natural products against PTM larvae on potato leaves var. "Nicola " at El-Delangate Region in El- Behera Governorate

\begin{tabular}{|c|c|c|c|c|c|c|c|c|c|c|}
\hline \multirow{4}{*}{ Treatments } & \multirow{4}{*}{ Rates / 100L water } & \multicolumn{9}{|c|}{ Numbers of larvae per 40 leaves $(\mathrm{A})$ and $(\%)$ reduction rates (B) } \\
\hline & & \multirow{3}{*}{ Pre- spray } & \multicolumn{6}{|c|}{ Spraying times } & \multirow{2}{*}{\multicolumn{2}{|c|}{ Mean }} \\
\hline & & & \multicolumn{2}{|c|}{$1^{\text {st }}$} & \multicolumn{2}{|c|}{$2^{\text {nd }}$} & \multicolumn{2}{|c|}{$3^{\text {rd }}$} & & \\
\hline & & & A & $\mathrm{B}$ & A & $\mathrm{B}$ & A & $\mathrm{B}$ & A & B $\%$ \\
\hline \multicolumn{11}{|c|}{ Winter 2004-2005 plantation season } \\
\hline \multirow{2}{*}{ Spinosad } & $30 \mathrm{ml}$ & 16 & 1 & 94.53 & 1 & 94.85 & 2 & 90.79 & 1.33 & $93.39 \mathrm{a}$ \\
\hline & $20 \mathrm{ml}$ & 14 & 2 & 87.50 & 2 & 88.24 & 2 & 89.47 & 2.00 & $88.40 \mathrm{a}$ \\
\hline \multirow{2}{*}{ Azadirachtin } & $187.5 \mathrm{ml}$ & 14 & 3 & 81.25 & 4 & 76.47 & 3 & 84.21 & 3.33 & $80.64 b$ \\
\hline & $140.6 \mathrm{ml}$ & 16 & 4 & 78.13 & 5 & 74.26 & 6 & 72.37 & 5.00 & $74.92 \mathrm{~b}$ \\
\hline \multirow{2}{*}{ ( Soybean oil) } & $625 \mathrm{ml}$ & 13 & 5 & 66.35 & 8 & 49.32 & 7 & 60.32 & 6.67 & $58.66 \mathrm{c}$ \\
\hline & $468.5 \mathrm{ml}$ & 11 & 7 & 44.32 & 7 & 47.59 & 9 & 39.71 & 7.67 & $43.87 d$ \\
\hline \multicolumn{2}{|c|}{ Check } & 14 & 16 & - & 17 & - & 19 & - & 17.33 & - \\
\hline \multicolumn{11}{|c|}{ Summer 2005 plantation season } \\
\hline \multirow{2}{*}{ Spinosad } & $30 \mathrm{ml}$ & 32 & 2 & 94.49 & 3 & 92.19 & 4 & 90.85 & 3.00 & $92.51 \mathrm{a}$ \\
\hline & $20 \mathrm{ml}$ & 33 & 3 & 91.98 & 4 & 89.90 & 5 & 88.91 & 4.00 & $90.26 \mathrm{bc}$ \\
\hline \multirow{2}{*}{ Azaderachten } & $187.5 \mathrm{ml}$ & 28 & 6 & 81.09 & 6 & 82.14 & 8 & 79.09 & 6.67 & $80.78 \mathrm{~d}$ \\
\hline & $140.6 \mathrm{ml}$ & 31 & 9 & 74.38 & 12 & 67.74 & 13 & 69.32 & 11.33 & $70.48 \mathrm{e}$ \\
\hline \multirow{2}{*}{ (Soybean oil) } & $625 \mathrm{ml}$ & 32 & 11 & 69.67 & 16 & 58.33 & 18 & 58.84 & 15.00 & $62.28 \mathrm{e}$ \\
\hline & $468.5 \mathrm{ml}$ & 32 & 16 & 55.88 & 18 & 53.13 & 24 & 45.12 & 19.33 & $51.38 \mathrm{~h}$ \\
\hline \multicolumn{2}{|c|}{ Check } & 30 & 34 & - & 36 & - & 41 & - & 37.00 & - \\
\hline
\end{tabular}




\section{REFERENCES}

1. Abbassy, M. A. , H. I. Omar and Walaa A. Yones . 2008. Development of IPM techniques of leafminaer, liriomyza trifolii (BURGESS) on common bean, Phaseolus vulgaris I. Egypt j.Agric. Res.,86(4) : 1305-1315 .

2. Amany S. El-Hefny and Sh. S. Yacoub 2010. Influence of some plant extracts on certain biological aspecis of Sesamia cretica led. Under laboratory conditions. Egypt. J. Agric. Res., $88: 113-121$.

3. Boyd, M. L. and D. J. Boethel. 1998. Susceptibility of predaceous hemipteran species to selected insecticides on soybean in Louisiana. J. Econ. Entomol . $91: 401-409$.

4. Doss, S. A. 1984 . Relative susceptibility of seventeen potato varieties to infestations by three insect pests in the field and the density of potato tuber moth infestation in stores. Bulletin de la Societe Entomologique d' Egypte, $65: 157-167$.

5. Duncan, D. B. 1955 . Multiple range and multiple F. tests. Biometrice 11 (1) : $1-42$.

6. Fetoh, B. E. A. 2003 . Development and implementation of integrated pest management against certain potato pest in Egypt. Ph.D. Thesis, faculty of Science Ain Shams Univ. , Cairo, Egypt, 126 pp.

7. Hofte, H. and H.R. Whiteley . 1989. Insecticidal crystal proteins of $B$. thuringiensis. Microbiol. Rev . $53: 242-255$.

8. Kirschbaum , J. B. 1985 . Potential implications of genetic engineering and other biotechnologies to insect control. Ann. Rev. Entomol . 30 : 51- 70 .

9. Liu, D. and J. T. Trumble 2005. Interactions of plant resistance and insecticides on the development and survival of Bactericerca cockerelli [ Sulc ] ( Homoptera : Psyllidae ). Crop Protection, 24 : 111-117.

10. Mertz, F. P. and R. C. Yao. 1990. Saccharopolyspora spinosad sp. nov isolated from soil collected in a sugar mill rum still. Int . J. Syst Bacteriol . 40 : $34-39$.

11. Mordue A. J. and A. Blackwell 2003. Azadirachtin. http// www.Sciencedirect.com . 
12. Mullins, J. W. 1993. Imidacloprid, A. New Nitroguanidine Insecticide. American Chemical Society Symposium in Newer Pest Control Agents and Technology with Reduced Environmental Impact. Miles Inc. Agriculture Division, Kansas eity MO 64120 .

13. Raslan, S. A. A., W. M. H. Desuky , A. E. Amer and A. A. A. El-Sayed 2009. Efficiency of nature product emamectin benzoat against cotton leafworm, Spodoptera littoralis (biosd) and pink bollwork, Pectinophora gossypiella (Saund) Egypt. J. Agric. Res., Egypt, : 999 - 1007 .

14. Sporleder, M., J. Kroschel , M. R. Gutierrez and A. Lagnaoui 2004 . A temperature - based simulation model for the potato tuberworm ( $P$ h. operculella (Zeller ) ( Lepidoptera : Gelechiidae ). Envirno. Entomol . : 33 (3) : 477 . 


\title{
استخام ثلاث طرق من أسلوب المكافحة المتكاملة لمكافحة فراشة درنات البطاطس
}

\section{Phthorimaea operculella (Zeller) ( Lepidoptera : Gelechiidae )}

\author{
على نباتات البطاطس
}

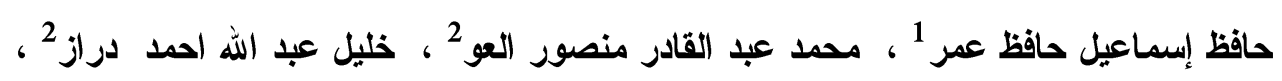

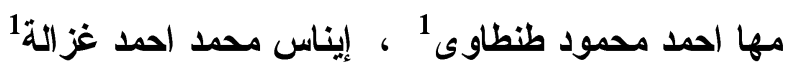

$$
\begin{aligned}
& \text { 1- قسم بحوث حشرات الخضر - معهز بحوث وقاية النباتات - مركز البحوث الزرراعية - دقي }
\end{aligned}
$$

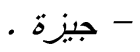

$$
\begin{aligned}
& 2 \text { - كلية النزراعة - جامعة الإسكندرية - فرع دنهور. }
\end{aligned}
$$

أجريت هذه الدراسة بمحطة البحوث الزراعية ايتاب البارود ، مركز البحوث الزراعية ،

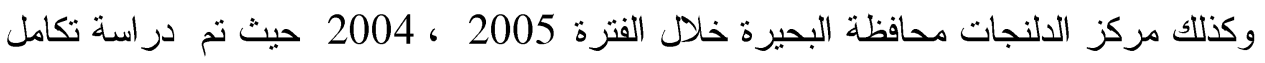

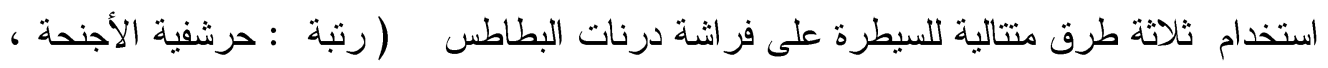

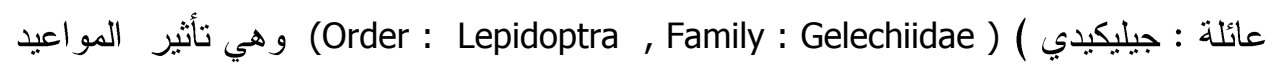

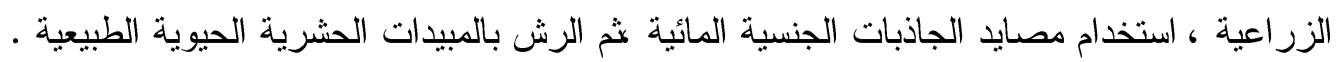

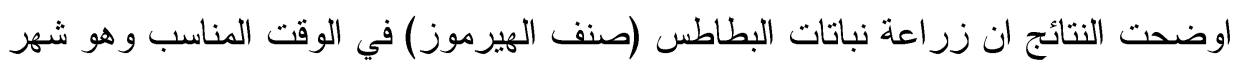

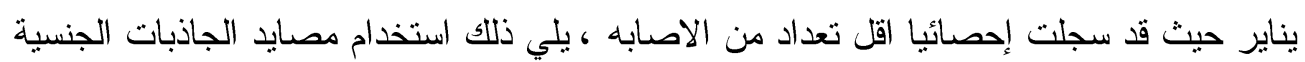

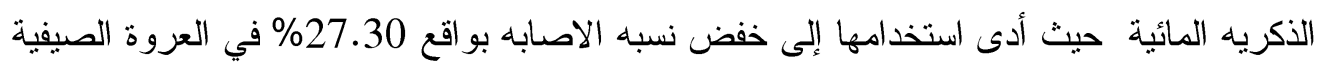

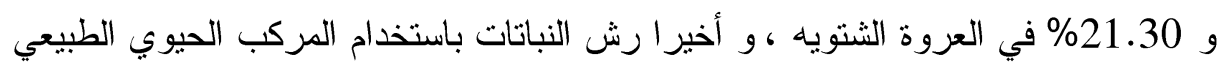

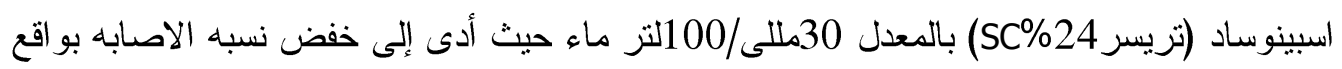
93.39\% أو المركب الحيوي النباتي اذانراختين (الشوك

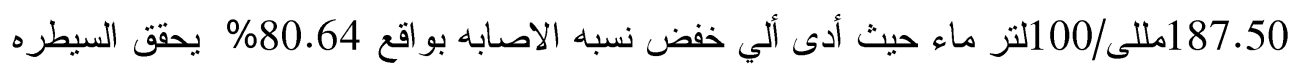

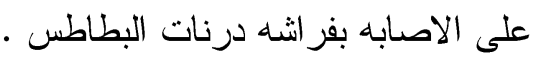

